\title{
PERANCANGAN MUROTTAL OTOMATIS MENGGUNAKAN MIKROKONTROLLER ARDUINO MEGA 2560
}

\author{
JauhariArifin, Leni Natalia Zulita, Hermawansyah \\ Program Studi Teknik Komputer Fakultas Ilmu Komputer Universitas Dehasen Bengkulu \\ Jl. Meranti Raya No. 32 Kota Bengkulu 38228 Telp. (0736) 22027, 26957 Fax. (0736) 341139
}

\begin{abstract}
The research Scheme of Automatic Murottal Use Microkontroller Arduino Mega 2560 designed to facilitate work of custodian of mosque when seedang not residing in place so that when time of sholat have almost arrive hence appliance of ni can turn around holy sentence bouncing movement Al Qu'An automatically. Research Laboratory of Hardware Study Program Computer Engineering Faculty Computer Science University of Dehasen Bengkulu, In July - September 2015. Data method which used in this research Method Documentation, Observation, and Study Book.Result of from this research obtained Conclusion that is automatic murottal can use Application Ianguage of Program Visual Basic 6.0 can be by 2 the way of that is: Automatically and Manual, Automatically by chosening letter to turning around and lead the time twiddling before adzan fill the air, while manually will be controlled to Application appearance with clicking one of the button exist in application of interface computer.

Keyword: Real Time Clock (RTC), Microkontroller Arduino Mega 2560, Ianguage of Visual Basic 6.0 program
\end{abstract}

\section{INTISARI}

Tujuan Perancangan Murottal Otomatis Menggunakan Mikrokontroller Arduino Mega 2560 dirancang untuk memudahkan pekerjaan penjaga masjid ketika sedang tidak berada di tempat sehingga ketika waktu sholat sudah hampir tiba maka alat ni dapat memutar lantunan ayat suci Al Qu'an secara otomatis. Penelitian dilakukan di Laboratorium Hardware Program Studi Teknik Komputer Fakultas Ilmu Komputer Universitas Dehasen Bengkulu, Pada Bulan Juli September 2015. Metode data yang digunakan dalam penelitian ini adalah Metode Dokumentasi, Observasi, dan Studi Pustaka. Hasil dari penelitian ini diperoleh Kesimpulan bahwa murottal otomatis ini dapat menggunakan Aplikasi Bahasa Program Visual Basic 6.0 bisadilakukan dengan 2 cara yaitu: Secara Otomatis dan Manual, Secara otomatis dengan caramemilih surat yang akan di putar dan mengatur waktu pemutaran sebelum adzan berkumandang, sedangkan secara manual akan dikendalikan melalui tampilan Aplikasi dengan mengklik salah satu dari tombol yang ada pada aplikasi interface komputer.

Kata Kunci : Real Time Clock (RTC), Mikrokontroler Arduino Mega 2560, Bahasa Pemrograman Visual Basic 6.0

\section{PENDAHULUAN}

Seiring dengan perkembangan zaman dan ilmu pengetahuan teknologi (IPTEK) yang begitu besar berpengaruh dalam dunia pendidikan, industri, dan perkatoran di seluruh dunia. Para ilmuan mengembangkan komputer dari generasi pertama sampai dengan generasi sekarang.

Dikembangkanya komputer dari generasi ke generasi dengan apa yang dapat dirasakan pada saat ini, semua rancangan alat elektronik sudah hampir semuanya menggunakan sistem komputerisasi, dengan menggunakan sistem komputerisasi akan lebih memudahkan dalam membantu pekerjaan manusia.

Dalam sistem komputerisasi juga dibutuhkan murottal yang biasa terdengar sebelum datangnya adzan seperti lantunan ayat-ayat suci Al-Qur'an, yang di implementasikan pada masjid-masjid dan mushollah yang memiliki prinsip kerja otomatis, dengan di terapkannya sebuah sistem otomatis untuk murottal akan lebih memudahkan penjaga masjid ataupun mushollah jika sedang dalam kesibukan ataupun sedang tidak berada di masjidketika jam telah mendekati waktu sholat, maka murottal otomatis akan memutar lantunan ayat suci Al-Qur'an, hanya dengan menentukan waktu pemutaran murottal sesuai yang diinginkan misalkan 30 atau 15 menit sebelum berkumandangnya adzan, murottal otomatis ini akan memutar lantunan ayat Al-Qur'an dengan sendirinya sesuai dengan waktu sholat setempat.

\section{TINJAUAN PUSTAKA}

\section{A) Pengertian Rancangan}

Menurut Al-Bahra Bin Ladjamudin (2005 : 39), menyebutkan bahwa: Perancangan adalah suatu kegiatan yang memiliki tujuan untuk mendesign sistem baru yang dapat menyelesaikan masalahmasalah yang dihadapi perusahaan yang diperoleh dari pemilihan alternatif sistem yang terbaik.

Definisi perancangan menurut Jogiyanto H.M (2005:196), Perancangan merupakan desain sistem menentukan bagaimana suatu sistem akan menyelesaikan apa yang mesti diselesaikan, tahap ini menyangkut mengkonfigurasi dari komponenkomponen perangkat lunak dan perangkat keras dari suatu sistem sehingga setelah instalasi dari sistem 
akan benar-benar memuaskan rancang bangun yang telah ditetapkan pada akhir tahap analasis sistem.

Berdasarkan uraian di atas dapat disimpulkan bahwa perancangan merupakan langkah awal untuk membuat suatu sistem yang baru guna menyelesaikan masalah-masalah dari sistem yang lama, melalui tahapan analisis terlebih dahulu

\section{B) Pengertian Murottal}

Menurut Heru (2008:12), Murottal merupakan kata lain dari bacaan Al-Qur'an yang di bacakan oleh seorang qori' dan di rekam baik berbentuk $\mathrm{CD}$ maupun Kaset, dengan irama tertentu, membaca AlQuran yang memfokuskan pada dua hal yaitu kebenaran bacaan dan lagu Al-Quran.

\section{C) Pengertian Arduino}

Arduino adalah platform pembuatan prototipe elektronik yang bersifat open-source hardware yang berdasarkan pada perangkat keras dan perangkat lunak yang fleksibel dan mudah digunakan. Arduino ditujukan bagi para seniman, desainer, dan siapapun yang tertarik dalam menciptakan objek atau lingkungan yang interaktif.

Menurut Sulaiman (2012:1), Arduino merupakan platform yang terdiri dari software dan hardware. Hardware Arduino sama dengan mikrocontroller pada umumnya hanya pada arduino ditambahkan penamaan pin agar mudah diingat. Software Arduino merupakan software open source sehingga dapat di download secara gratis. Software ini digunakan untuk membuat dan memasukkan program ke dalam Arduino. Pemrograman Arduino tidak sebanyak tahapan mikrokontroller konvensional karena Arduino sudah didesain mudah untuk dipelajari, sehingga para pemula dapat mulai belajar mikrokontroller dengan Arduino.

Berdasarkan uraian diatas, dapat disimpulkan bahwa arduino merupakan platform pembuatan prototipe elektronik yang terdiri dari hardware dan softaware.

\section{1) Hardware Arduino}

Menurut Feri Djuandi (2011:8), Komponen utama didalam papan Arduino adalah sebuah 8 bit dengan merk ATmega yang dibuat oleh Atmel Corporation. Berbagai papan Arduino menggunakan tipe ATmega yang berbeda-beda tergantung dari spesifikasinya, sebagai contoh Arduino Uno menggunakan ATmega328 sedangkan Arduino Mega 2560 yang lebih canggih menggunakan ATmega2560.

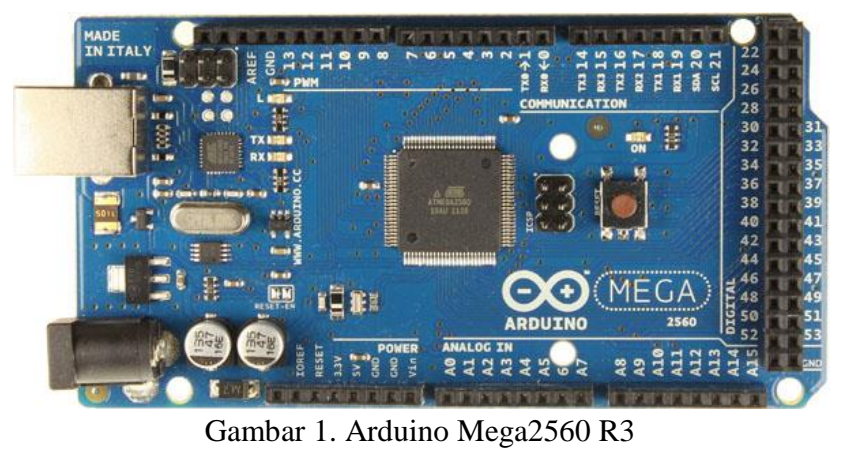

Adapun data teknis board Arduino Mega2560 adalah sebagai berikut:

Tabel 1. Data Teknik Board Arduino Mega 2560

\begin{tabular}{|l|l|}
\hline Digital I/O Pins & $\begin{array}{l}54 \text { (of which 15 provide } \\
\text { PWM output) }\end{array}$ \\
\hline Analog Input Pins & 16 \\
\hline DC Current per I/O Pin & $40 \mathrm{~mA}$ \\
\hline $\begin{array}{l}\text { DC Current for 3.3V } \\
\text { Pin }\end{array}$ & $50 \mathrm{~mA}$ \\
\hline Flash Memory & $\begin{array}{l}256 \mathrm{~KB} \text { of which } 8 \mathrm{~KB} \\
\text { used by bootloader }\end{array}$ \\
\hline SRAM & $8 \mathrm{~KB}$ \\
\hline EEPROM & $4 \mathrm{~KB}$ \\
\hline Clock Speed & $16 \mathrm{MHz}$ \\
\hline
\end{tabular}

Arduino Mega2560 Revisi 3 memiliki fitur-fitur baru berikut:

a) 1.0 pinout : Ditambahkan pin SDA dan pin SCL yang dekat dengan pin AREF dan dua pin baru lainnya ditempatkan dekat dengan pin RESET, IOREF memungkinkan shield untuk beradaptasi dengan tegangan yang tersedia pada papan. Di masa depan, shield akan kompatibel baik dengan papan yang menggunakan AVR yang beroperasi dengan 5 Volt dan dengan Arduino Due yang beroperasi dengan tegangan 3.3 Volt. Dan ada dua pin yang tidak terhubung, yang disediakan untuk tujuan masa depan.

b) Sirkuit RESET.

c) Chip ATmega16U2 menggantikan chip ATmega8U2.

\section{2) Sumber Daya tegangan Arduino}

Menurut Feri Djuandi (2011:10), Arduino Mega dapat diaktifkan melalui koneksi USB atau dengan catu daya eksternal. Sumber daya dipilih secara otomatis. Sumber daya eksternal (non-USB) dapat berasal baik dari adaptor AC-DC atau baterai. Adaptor dapat dihubungkan dengan mencolokkan steker 2,1 mm yang bagian tengahnya terminal positif ke ke jack sumber tegangan pada papan. Jika tegangan berasal dari baterai dapat langsung 
dihubungkan melalui header pin Gnd dan pin Vin dari konektor POWER.

Papan Arduino mega2560 dapat beroperasi dengan pasokan daya eksternal 6 Volt sampai 20 volt. Jika diberi tegangan kurang dari 7 Volt, maka, pin 5 Volt mungkin akan menghasilkan tegangan kurang dari 5 Volt dan ini akan membuat papan menjadi tidak stabil. Jika sumber tegangan menggunakan lebih dari 12 Volt, regulator tegangan akan mengalami panas berlebihan dan bisa merusak papan. Rentang sumber tegangan yang dianjurkan adalah 7 Volt sampai 12 Volt.

Pin tegangan yang tersedia pada papan Arduino adalah sebagai berikut:

a) VIN : Adalah input tegangan untuk papan Arduino ketika menggunakan sumber daya eksternal (sebagai 'saingan' tegangan 5 Volt dari koneksi USB atau sumber daya ter-regulator lainnya). Anda dapat memberikan tegangan melalui pin ini, atau jika memasok tegangan untuk papan melalui jack power, kita bisa mengakses/mengambil tegangan melalui pin ini.

b) $5 \mathrm{~V}$ : Sebuah pin yang mengeluarkan tegangan ter-regulator 5 Volt, dari pin ini tegangan sudah diatur (ter-regulator) dari regulator yang tersedia (built-in) pada papan. Arduino dapat diaktifkan dengan sumber daya baik berasal dari jack power DC (7-12 Volt), konektor USB (5 Volt), atau pin VIN pada board (7-12 Volt). Memberikan tegangan melalui pin $5 \mathrm{~V}$ atau $3.3 \mathrm{~V}$ secara langsung tanpa melewati regulator dapat merusak papan Arduino.

c) $3 \mathrm{~V} 3$ : Sebuah pin yang menghasilkan tegangan 3,3 Volt. Tegangan ini dihasilkan oleh regulator yang terdapat pada papan (on-board). Arus maksimum yang dihasilkan adalah $50 \mathrm{~mA}$.

d) GND : Pin Ground atau Massa.

e) IOREF : Pin ini pada papan Arduino berfungsi untuk memberikan referensi tegangan yang beroperasi pada mikrokontroler. Sebuah perisai (shield) dikonfigurasi dengan benar untuk dapat membaca pin tegangan IOREF dan memilih sumber daya yang tepat atau mengaktifkan penerjemah tegangan (voltage translator) pada output untuk bekerja pada tegangan 5 Volt atau 3,3 Volt.

\section{3) Memori Arduino}

Arduino ATmega2560 memiliki $256 \mathrm{~KB}$ flash memory untuk menyimpan kode (yang $8 \mathrm{~KB}$ digunakan untuk bootloader), 8 KB SRAM dan $4 \mathrm{~KB}$ EEPROM (yang dapat dibaca dan ditulis dengan perpustakaan EEPROM).

\section{4) Software Arduino}

Arduino diciptakan untuk para pemula bahkan yang tidak memiliki basic bahasa pemrograman sama sekali karena menggunakan bahasa $\mathrm{C}++$ yang telah dipermudah melalui library. Arduino menggunakan Software Processing yang digunakan untuk menulis program kedalam Arduino. Processing sendiri merupakan penggabungan antara bahasa $\mathrm{C}++$ dan Java. Software Arduino ini dapat di-install di berbagai operating system (OS) seperti: LINUX, Mac OS, Windows. Arduino tidak hanya sekedar sebuah alat pengembangan, tetapi kombinasi dari hardware, bahasa pemrograman dan Integrated Development Environment (IDE) yang canggih. IDE adalah sebuah software yang sangat berperan untuk menulis program, meng-compile menjadi kode biner dan meng-upload ke dalam memory microcontroller.Software IDE Arduino terdiri dari 3 (tiga) bagian:

a) Editor program, untuk menulis dan mengedit program dalam bahasa processing. Listing program pada Arduino disebut sketch.

b) Compiler, modul yang berfungsi mengubah bahasa processing (kode program) kedalam kode biner karena kode biner adalah satu-satunya bahasa program yang dipahami oleh mikrocontroller.

c) Uploader, modul yang berfungsi memasukkan kode biner kedalam memori mikrokontroller.

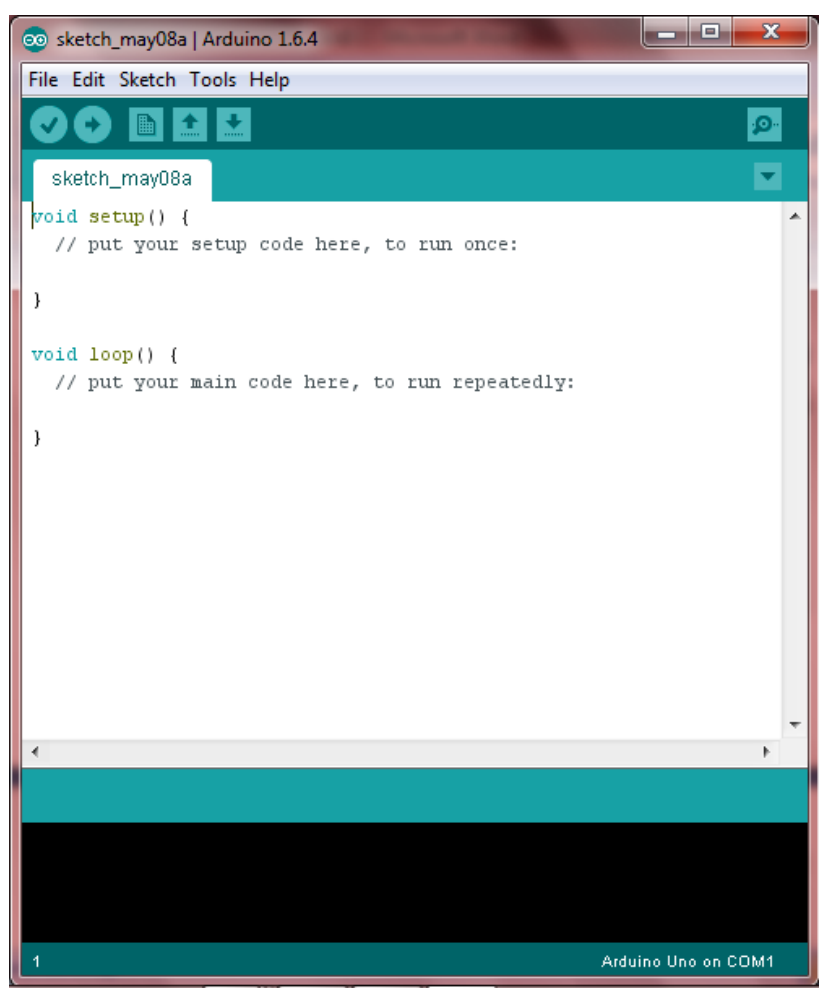

Gambar 2. Tampilan Software IDE Arduino 


\section{D) Pengertian Mikrokontroller}

Menurut Budiharto Widodo(2005:5), Mikrokontroller dapat dikatakan sebuah sistem komputer yang seluruhatau sebagian besar elemennya dikemas dalam satu chip sehingga sering disebut sebagai single chip mikrokomputer. Tidak seperti sistem komputer yang mampu menangani berbagai macam program aplikasi, mikrokontroller hanya dapat digunakan untuk suatu aplikasi saja. Perbedaan lainya yaitu pada perbandingan RAM (Rendom Acces Memory) dan ROM (Read Only Memory). Pada Mikrokontroller perbandingan antara RAM dan ROM-nya besar, sedangkan pada sistem komputer juga besar.

Menurut Dian Artanto (2008:27), Mikrokontrollermerupakan sistem komputer yang seluruh atau sebagian besar elemennyadikemas dalam satu chip IC sehingga sering juga disebut single chip microcomputer.

Dari kedua uraian diatas penulis menyimpulkan bahwa, mikrocontroller merupakan satu sistem komputer yang pada hakikatnya sebagian besar elemenya dikemas dalam satu chip IC.

\section{E) Mikrokontroller Arduino Mega2560}

Menurut Dian Artanto (2008:30), Mikrokontroller adalah piranti elektronik berupa Integrated Circuit (IC) yang memiliki kemampuan manipulasi data (informasi) berdasarkan suatu urutan instruksi (program) yang dibuat oleh programmer dimana di dalamnya sudah terdapat Central Proccesssing Unit (CPU), Random Acess Memory (RAM), Electrically Erasable Programmable Read Only Memori (EEPROM), I/O, Timer dan peralatan internal lainnya yang sudah saling terhubung terorganisasi dengan baik oleh pabrik pembuatnya dan dikemas dalam satu chip yang siap pakai. Umumnya mikrokontroler memiliki instruksi manipulasi bit, akses ke I/O secara langsung serta proses interupsi yang cepat dan efisien. Penggunaan mikrokontroler sudah banyak ditemui dalam berbagai peralatan elektronik, seperti telepon digital, microwave oven, televisi, dan lainlain. Mikrokontroller juga dapat digunakan untuk berbagai aplikasi dalam industri seperti: sistem kendali, otomasi, dan lain-lain.

\section{1) Konfigurasi Pin Arduino Mega 2560}

Menurut Dian Artanto (2008:34), Konfigurasi pin mikrokontroller ATmega 2560 adalah sebagai berikut:

a. VCC merupakan pin yang digunakan sebagai masukan sumber tegangan.

b. GND merupakan pin untuk Ground. c. XTAL1/ XTAL2, XTAL digunakan sebagai pin external clock.

d. Port A, B, C ,D, E, H, dan L merupakan 8 bit port I/O dengan internal pull-up resistor. Port G merupakan 6 bit port I/O dengan internal pull-up resistor.

e. Port F (PF0:PF7) dan Port K (PK0:PK7) merupakan pin $\mathrm{I} / \mathrm{O}$ dan merupakan pin masukan ADC.

f. AVCC adalah pin masukan untuk tegangan ADC.

g. AREF adalah pin masukan untuk tegangan referensi eksternal ADC.

Konfigurasi pin Arduino Mega2560 dapat dilihat pada gambar berikut:

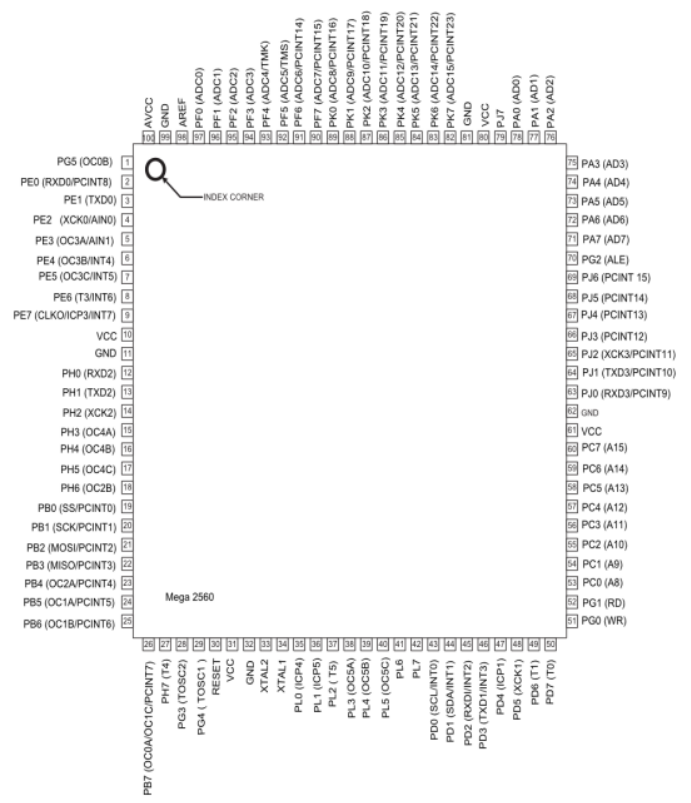

Gambar 3. Konfigurasi pin Arduino Mega2560

\section{F) Komponen-Komponen Elektronika}

Menurut Budiharto Widodo (2005:2) elektronika adalah ilmu yang mempelajari tentang sifat dan pemakaian devais yang azas kerjanya berdasarkan aliran elektron didalam ruang hampa atau gas dan aliran elektron serta lubang didalam semikonduktor. Penerapan elektronika mencakup antara lain untuk radio, tv, komputer, instrumen kendali dan peralatan komunikasi lainnya.

Berikut berbagai macam komponen elektonika yang umumnya digunakan dalam pembuatan rangkaian.

\section{1) Transistor}

Transistor adalah satu komponen elektronika yang memiliki tiga sambungan. Transistor adalah alat semikonduktor yang dipakai sebagai penguat, pemotong (switching), stabilisasi tegangan, modulasi 
sinyal atau fungsi lainnya. Transistor dapat berfungsi semacam kran listrik, dimana berdasarkan arus inputnya (BJT) atau tegangan inputnya (FET), memungkinkan pengaliran listrik yang sangat akurat dari sirkuit sumber listriknya.

\section{2) Resistor}

Resistor atau tahanan adalah salah satu komponen elektronika yang berfungsi untuk mengatur serta menghambat arus listrik. Resistor adalah komponen dasar elektronika yang dipergunakan untuk membatasi jumlah arus yang mengalir dalam suatu rangkaian. Sesuai dengan namanya resistor bersifat resistif dan biasanya komponen ini terbuat dari bahan karbon. Berdasarkan hokum Ohm bahwa resistansi berbanding terbalik dengan jumlah arus yang mengalir melaluinya. Satuan resistansi dari suatu resistor disebut $\mathrm{Ohm}$ atau dilambangkan dengan simbol W(Omega).

\section{3) Kapasitor}

Pengertian lain kapasitor adalah komponen elektronika yang dapat menyimpan dan melepaskan muatan listrik. Struktur sebuah kapasitor terbuat dari 2 buah plat metal yang dipisahkan oleh suatu bahan dielektrik. Bahan-bahan dielektrik yang umum dikenal misalnya udara vakum, keramik, gelas, elektrolit dan lain-lain.

Jika kedua ujung plat metal diberi tegangan listrik, maka muatan-muatan positif akan mengumpul pada salah satu kaki (elektroda) metalnya dan pada saat yang sama muatan-muatan negatif terkumpul pada ujung metal yang satu lagi. Muatan positif tidak dapat mengalir menuju ujung kutup negatif dan sebaliknya muatan negatif tidak bisa menuju ke ujung kutup positif, karena terpisah oleh bahan dielektrik yang non-konduktif. Muatan elektrik ini "tersimpan" selama tidak ada konduksi pada ujung-ujung kakinya. Kemampuan untuk menyimpan muatan listrik pada kapasitor disebuat dengan kapasitansi atau kapasitas.

\section{4) Dioda}

Dioda memiliki fungsi yang unik yaitu hanya dapat mengalirkan arus satu arah saja. Struktur dioda tidak lain adalah sambungan semikonduktor $\mathrm{P}$ dan $\mathrm{N}$. Satu sisi adalah semikonduktor dengan tipe $\mathrm{P}$ dan satu sisinya yang lain adalah tipe N. Dengan struktur demikian arus hanya akan dapat mengalir dari sisi $\mathrm{P}$ menuju sisi $\mathrm{N}$.

\section{5) IC (Integrated Circuit)}

IC (Integrated Circuit) adalah Komponen Elektronika Aktif yang terdiri dari gabungan ratusan bahkan jutaan Transistor, Resistor dan komponen lainnya yang diintegrasi menjadi sebuah Rangkaian Elektronika dalam sebuah kemasan kecil. Bentuk IC (Integrated Circuit) juga bermacam-macam, mulai dari yang berkaki 3 (tiga) hingga ratusan kaki (terminal). Fungsi IC juga beraneka ragam, mulai dari penguat, Switching, pengontrol hingga media penyimpanan. Pada umumnya, IC adalah Komponen Elektronika dipergunakan sebagai Otak dalam sebuah Peralatan Elektronika. IC merupakan komponen Semi konduktor yang sangat sensitif terhadap ESD (Electro Static Discharge).

\section{G) Bahasa Pemrograman Visual Basic 6.0}

Menurut Andi (2002), Visual Basic merupakan cara termudah dan tercepat untuk membuat aplikasi yang dijalankan di sistem operasi Microsoft Windows. Untuk seorang profesional atau pemula sekalipun di bidang pemrograman Windows, Visual Basic menyediakan sekumpulan perangkat untuk mempermudah dan menyederhanakan pengembangan aplikasi yang tangguh.

Kata "Visual" merujuk kepada metode yang digunakan untuk membuat antar muka yang bersifat grafis Graphical User Interface (GUI). Daripada menulis berbaris-baris kode untuk menjelaskan pemunculan dan lokasi dari suatu elemen di dalam antar muka, dengan mudah dapat menambahkan object yang sebelumnya sudah dibangun ke dalam tempat dan posisi yang Anda inginkan di layar.

Kata "Basic" merujuk kepada bahasa BASIC (Beginners All-Purpose Symbolic Instruction Code), sebuah bahasa yang digunakan oleh banyak programmer dibandingkan dengan bahasa lainnya dalam sejarah komputer. Visual Basic telah berubah dari bahasa asli BASIC dan sekarang memiliki ratusan pernyataan (statements), fungsi (functions), dan kata kunci (keywords), dan kebanyakan di antaranya terkait dengan antar muka grafis di Windows. Pengguna tingkat pemula sekalipun dapat membuat aplikasi dengan mempelajari hanya beberapa kata kunci, sementara kekuatan dari bahasanya membolehkan para pengguna tingkat professional mencapai apapun yang dapat dihasilkan dengan menggunakan bahasa pemrograman Windows lainnya.

\section{METODOLOGI PENELITIAN}

\section{A) Metode Penelitian}

Metode penelitian yang digunakan adalah metode eksperimen, dimana dalam penelitian akan dibuat sebuah rancangan alat yang mampu berjalan dengan otomatis untuk menjalankan suara murottal sebelum 
dikumandangkanya adzan ketika waktu sholat tiba, dengan output suara menggunakan arduino mega2560 yang berbasis mikrokontroller Arduino Mega2560. Alat ini terdiri dari papan Arduino, mikrokontroller Arduino mega2560, LCD (Liquid Crystal Display), RTC (real time clock), dan PC(Personal Computer). Setelah semua bahan untuk membuat alat telah siap maka kita akan merangkai alat-alat tersebut, sampai alat tersebut aktif dan bisa digunakan sesuai dengan kegunaanya.

\section{B) Instrumen Penelitian}

\section{1) Perangkat Keras}

Perangkat keras yang digunakan dalam penelitian antara lain adalah pada tabel dibawah ini

Tabel 2. Alat dan Bahan yang akan digunakan dalam Penelitian

\begin{tabular}{|l|l|}
\hline \multicolumn{1}{|c|}{ Alat / Bahan } & \multicolumn{1}{c|}{ Spesifikasi } \\
\hline Mikrokontroler & Arduino Mega2560 \\
\hline Tombol input & Digital Switch \\
\hline tombol reset & Digital switch \\
\hline LCD & LCD 16 x 2 black green \\
\hline IC RTC & IC DS1307 \\
\hline Amplifier & Amplifier OCL \\
\hline Kapasitor & Elco \\
\hline Transformator & Transformator 1a Ct (Center Tap) \\
\hline Kabel & Kabel halus \\
\hline Stecker & Standar \\
\hline konektor ke PC & Konektor DB9 \\
\hline LED & LED 3mm \\
\hline saklar power & Saklar on off \\
\hline Solder & Solder 40W 220 V \\
\hline Timah & Timah standar \\
\hline Tang & Tang potong dan runcing \\
\hline Obeng & Obeng plus dan minus \\
\hline Tubing kabel & Pembungkus Kabel 1mm \\
\hline pcb sistem minimum & Pcb sistem minimum atmega16 \\
\hline Box & Akrilik 2mm \\
\hline baut dan mur & Secukupnya \\
\hline
\end{tabular}

\section{2) Perangkat Lunak}

Perangkat lunak yang digunakan meliputi sistem operasi, bahasa pemrograman dan perangkat lunak pengolahan data. Sistem operasi yang digunakan adalah microsoft windows7, Bahasa pemrograman yang digunakan adalah Bahasa pemrograman Microsoft visual basic 6.0 dan IDE Arduino.

\section{C) Metode Perancangan Sistem}

\section{1) Blok Diagram Global}

Blok diagram global dari Murottal otomatis dengan output suara dapat dilihat pada gambar berikut ini :

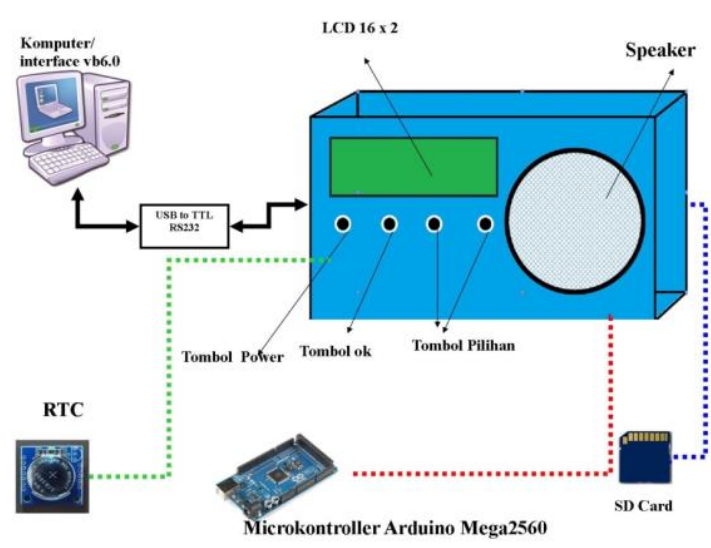

Gambar 4. Blok Diagram Global

Keterangan :

a) SD card berfungsi sebagai memori penympanan MP3 murottal Al Qur'an.

b) RTC berfungsi sebagai penghitung waktu

c) PC atau komputer terhubung ke rangkaian mikrokontroller dengan media penghubung RS232 yang dihubungkan ke papan arduino yang di dalam nya terdapat microkontroller Arduino mega2560.

d) Pilihan untuk mengatur murottal yang akan terputar dapat juga diatur melalui aplikasi yang di bangun dengan VB 6.0, yang berfungsi sebagai aplikasi interface dari komputer ke rancangan alat.

e) LCD Berfungsi sebagai output time atau waktu hitung mundur ketika akan masuknya waktu Sholat dan pemberitahuan surah apa yang sedang di bacakan.

f) Mikrokontroller berfungsi untuk mengolah data yang akan dikirim ke komputer.

g) RS232 berfungsi sebagai jembatan antara mikrokontroller dengan komputer.

h) Speaker berfungsi untuk menghasilkan output berupa suara yang nantinya suara yang terputar ialah lantunan ayat-ayat suci al qur'an

\section{2) Blok Diagram Rangkaian}

Desain rangkaian murottal otomatis dan blok diagram rangkaian dapat dilihat seperti dibawah ini: 


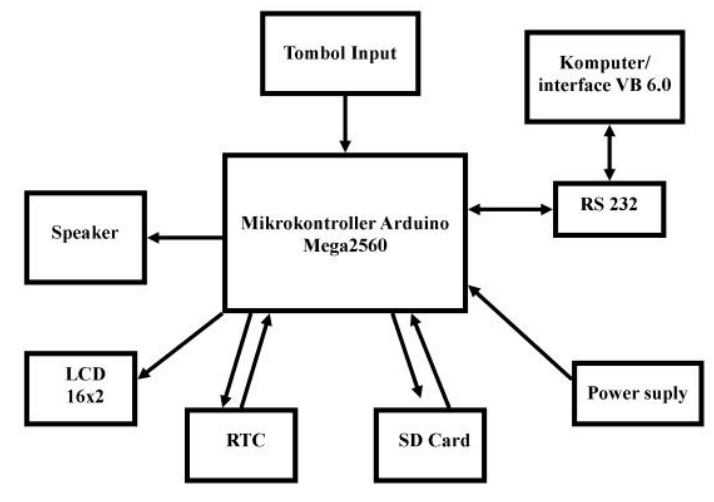

Gambar 5. Tampilan Blok Diagram Rangkaian Alat

Keterangan Gambar:

a) Komputer berfungsi sebagai penerima dan pemberi perintah kepada mikrokontroller dengan melalui penghubung RS232..

b) Perintah yang diterima dari PC diolah oleh mikrokontroller dan hasil pengolahan tersebut akan diteruskan ke Speaker dan ditampilkan pada LCD $16 \times 2$.

c) RTC berfungsi untuk melakukan perhitungan waktu dari detik, menit, jam, dan tanggal dalam pemutaran murrotal.

\section{3) Desain Rangkaian Alat}

Blok diagram rangkaian murottal otomatis dengan output suara menggunakan mikrokontroller Atmega2560, antara lain menggunakan mikrokontroler Atmega2560,LCD (Liquid Crystal Display), USB to TTL atau RS232 (Max232), tampilan blok diagram rangkaian alat dapat dilihat pada tampilan berikut ini.

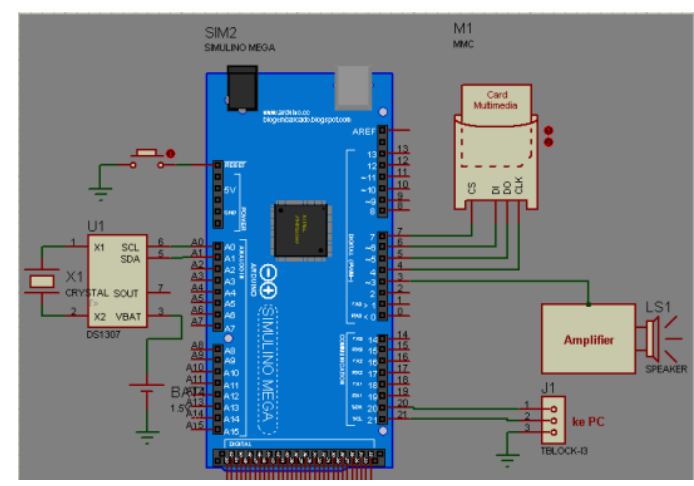

Gambar 6. Tampilan Desain rangkaian Alat

\section{4) Prinsip Kerja}

Prinsip kerja alat melalui tombol yang difungsikan sebagai tombol menu pilihan, yang bisa digunakan untuk memilih surat yang akan diputar. Setelah surat dipilih, kemudiandengan menekan tombol ok untuk memproses surat yang telah terpilih untuk diputar terlebih dahulu oleh rangkaian alat yang tersimpan pada SD Card dengan pilihan waktu yang di inginkan, pembacaan murottal akan berhenti 5 menit sebelumwaktu sholat tiba tepatnya sebelum adzan di kumandangkan, sesuai dengan jadwal sholat waktu setempat.

\section{5) Rencana Rancangan Aplikasi Alat Pada PC}

a) Properti Setting

Untuk membuat aplikasi pada pc terlebih dahulu penulis menentukan properti setting pada bahasa pemograman. Seperti pada table berikut ini :

Tabel 3. Rencana Property Setting

\begin{tabular}{|c|l|l|l|}
\hline No & Object & properti & \multicolumn{1}{|c|}{ setting } \\
\hline 1 & Form 1 & $\begin{array}{l}\text { Name } \\
\text { Caption }\end{array}$ & $\begin{array}{l}\text { Form1 } \\
\text { MUROTTALL }\end{array}$ \\
\hline 2 & Label1 & $\begin{array}{l}\text { Name } \\
\text { Caption }\end{array}$ & $\begin{array}{l}\text { judul } \\
\text { Murrotal otomatis }\end{array}$ \\
\hline 3 & Frame1 & $\begin{array}{l}\text { Name } \\
\text { Caption }\end{array}$ & $\begin{array}{l}\text { Frame1 } \\
\text { Pilihan setting } \\
\text { hardware }\end{array}$ \\
\hline 4 & Teks1 & $\begin{array}{l}\text { Name } \\
\text { Teks } \\
\text { Locked }\end{array}$ & Text1 \\
True
\end{tabular}

b) Rencana Tampilan Aplikasi Alat Pada PC

Untuk Rencana Desain Rancangan Tampilan Program Aplikasi murottal otomatis dengan output suara menggunakan Arduino Mega2560 ini penulis menggunakan bahasa pemograman Visual Basic 6.0, yaitu dengan tampilan sebagai berikut :

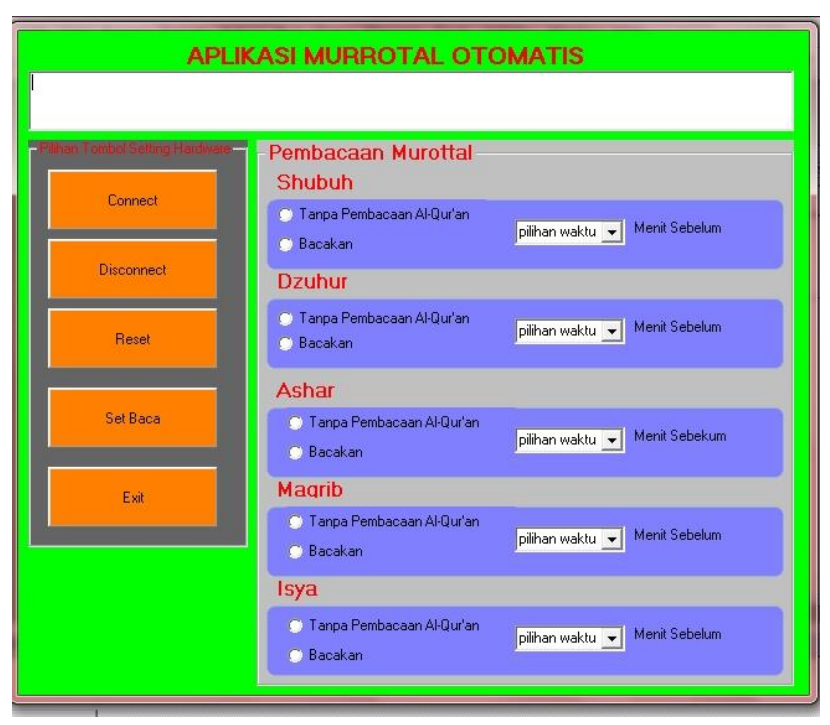

Gambar 7. Rencana Rancangan Program 
Keterangan Gambar:

1) Aplikasi Murottal otomatis dengan output suara menggunakan mikrokontroller Arduino mega2560 pada PC ini penulis beri nama Aplikasi Murottal Otomatis dan dibuat dengan menggunakan bahasa pemrograman VB 6.0.

2) Pada bagian Setting terdapat 5 tombol:

a) Connect untuk melakukan atau menghubungkan alat dengan aplikasi.

b) Disconnect untuk melakukan pemutusan hubungan atau koneksi dengan antara alat dan aplikasi.

c) Reset untuk mereset ulang aplikasi.

d) Keluar berfungsi untuk keluar dari aplikasi

e) Set Baca berfungsi sebagai pemberi perintah terhadap rangkaian mikrokontroller untuk waktu pembacaan murottal.

\section{6) 3.5.6 Rencana Kerja}

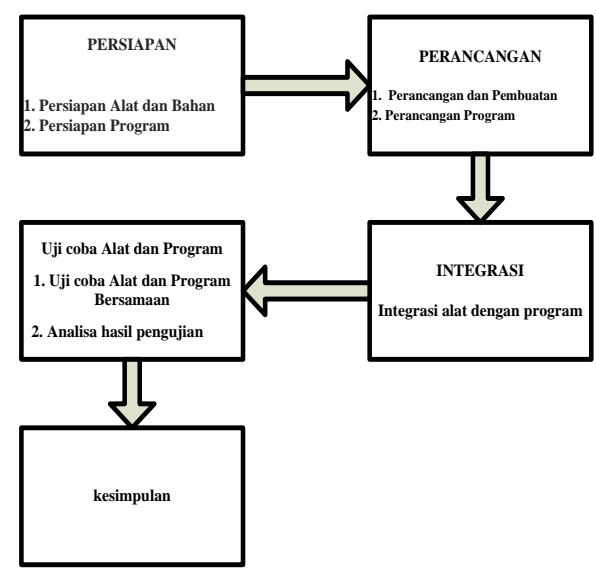

Gambar 8. Rencana Kerja

\section{D) Rancangan Pengujian Sistem}

Pengujian sistem dilakukan di Laboratorium metode black box yaitu dengan menguji kemampuan sistem berdasarkan spesifikasi yang telah ditentukan. Pengujian sistem dilakukan terhadap kemampuan sistem berupa:

1) Kemampuan mikrokontroller mengolah data yang diterima dari PC.

2) Ketepatan dan kemampuan aplikasi yang ada untuk menghasilkan dan mengirim suara ke speaker.

\section{PEMBAHASAN}

A) Hasil

1) Pembuatan Murottal Otomatis Menggunakan Mikrokontroller Arduino Mega 2560

Murottal Otomatis ini terdiri dari beberapa bagian komponen yaitu: RTC (real time clock), Mikrokontroler Arduino Mega 2560, LCD (Liquid
Cristal Display) dan Komputer sebagai penampil data melalui Program Visual Basic 6.0. Berikut adalah gambar Rangkaian Murottal otomatis dengan menggunakan mikrokontroller arduino mega 2560 dapat dilihat pada gambar dibawah ini :

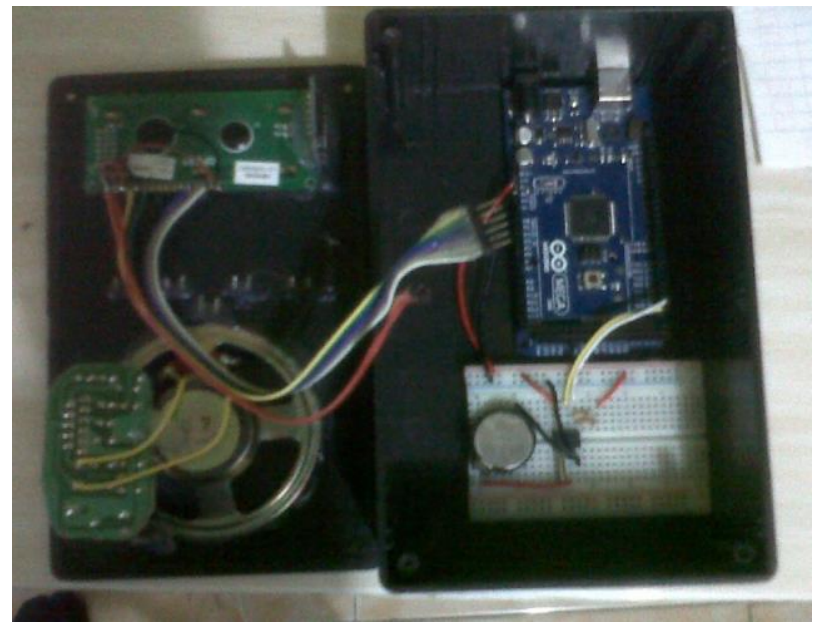

Gambar 9. Rangkaian Murottal Otomatis

\section{2) Aplikasi Murottal Otomatis Menggunakan Mikrokontroller Arduino Mega 2560}

Aplikasi yang digunakan untuk membuat murottal otomatis ini dengan menggunakan bahasa pemrograman microsoft visual basic 6.0 dapat di lihat pada Gambar 10.

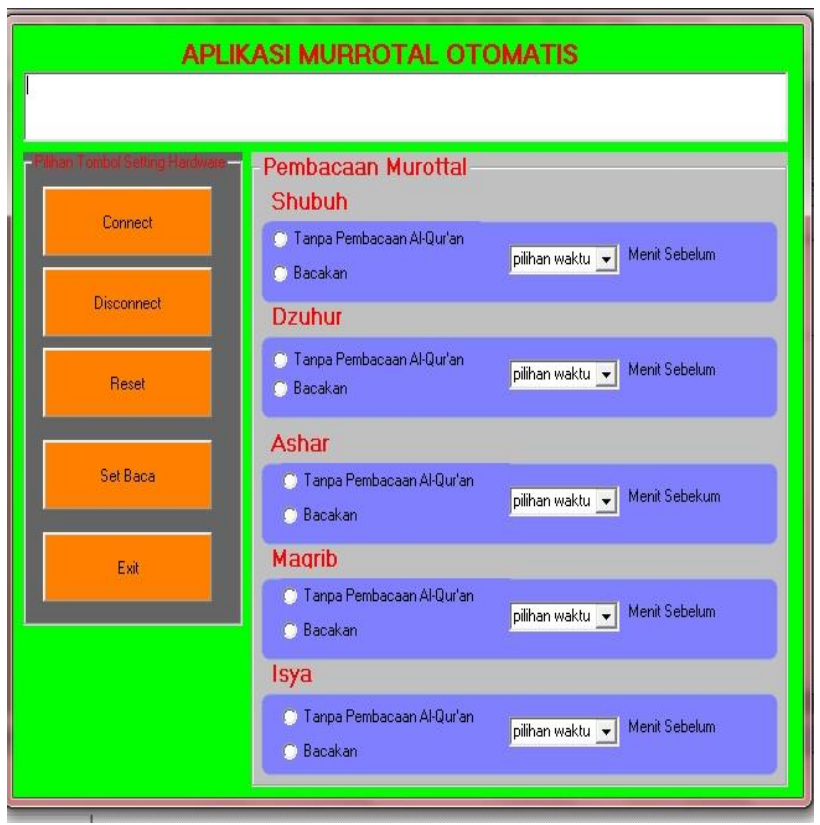

Gambar 10. Tampilan Aplikasi Murottal Otomatis

\section{3) Prosedur Pengoprasian Aplikasi dan Alat}

Murottal otomatis ini dapat bekerja dengan menghubungkanya melalui komputer dan bekerja secara otomatis. Adapun prosedur untuk mengoprasikan alat ini dapat di jelaskan seperti berikut ini : 
a) Menghubungkan dengan komputer.

b) Menghubungkan konektor USB-232 ke colokan USB Komputer.

c) Menjalankan aplikasi pada komputer

d) Setting port perintah berfungsi untuk melakukan setting port koneksi antara pc dan alat.

e) Setting port input berfungsi untuk melakukan setting port koneksi antara pc dan aplikasi.

f) Data masuk adalah menampilkan proses pengiriman data dari alat (rankaian mikrokontroller) ke aplikasi pc.

\section{B) Hasil Uji Coba}

Dari hasil uji coba Alat dan Program, diketahui Respon Alat terhadap perintah-perintah dari Aplikasi berjalan dengan normal atau berhasil. Keberhasilan dari hasil ujicoba alat dapat dilihat pada Tabel 4, 5, dan 6.

\section{PENUTUP}

A) Kesimpulan

1) RTC ( Real Tima Clock) digunakan sebagai penghitung waktu yang menjadi titik acuan untuk terputarnya lantunan ayat suci Al-Qur'an pada tiap tiap waktu sholat.

2) Mikrokontroler Arduino Mega 2560 dapat digunakan untuk mengolah data dari RTC dan dikirimkan ke Aplikasi pada Komputer melalui Port Serial.

3) Dari hasil pengujian alat diketahui bahwa proses pemutaran murottal otomatis dapat diputar pada lima waktu sholat tergantung pada perintah yang di berikan pada alat ingin di putar pada tiap-tiap waktu sholat atau pada umumnya murottal biasa diputar pada saat subuh dan magrib dapat di atur pada aplikasi interface pada komputer.

Tabel 4. Hasil Pengujian Alat Tahap Pertama

\begin{tabular}{|c|l|l|}
\hline No & \multicolumn{1}{|c|}{ Pengujian } & \multicolumn{1}{c|}{ Kemampuan } \\
\hline 1 & RTC & $\begin{array}{l}\text { Pengujian RTC (Real time Clock) belum mampu menhitung waktu atau menampilkan jam } \\
\text { dan tanggal dikarenakan program pada Ide Arduino masih eror lantaran Library program } \\
\text { untuk RTC Tidak sesuai dengan Tipe RTC yang di gunakan. }\end{array}$ \\
\hline 2 & Speaker & $\begin{array}{l}\text { Speaker telah mampu untuk memberikan output berupa seuara akan tetapi suara yang di } \\
\text { keluarkan belum maksimal dikarenakan program yang di tanam pada mikrokontroller belum } \\
\text { sempurna. }\end{array}$ \\
\hline 3 & LCD 16 x2 & $\begin{array}{l}\text { LCD (liquid Crystal Display)sudah dapat menampilkan text atau tulisanakan tetapi masih } \\
\text { banyak untuk library program yang harus di rubah untuk mendapat hasil yang lebih sempurna. }\end{array}$ \\
\hline 4 & $\begin{array}{l}\text { Aplikasi Pada } \\
\text { Komputer }\end{array}$ & $\begin{array}{l}\text { Aplikasi interface pada komputer dengan visual basic 6.0, setelah di racang desain aplikasi } \\
\text { dan di berikan listing program. Program jalan dengan baik dan mampu untuk memberi } \\
\text { perintah ke rangkaian mikrokontroller untuk memutar murottal. }\end{array}$ \\
\hline 5 & $\begin{array}{l}\text { Rangkaian } \\
\text { Mikro } \\
\text { Kontroller }\end{array}$ & $\begin{array}{l}\text { Penanaman program pada mikrokontroller dapat beroprasi dengan baik akan tetapi } \\
\text { mikrokontroller belum dapat membaca SD Card. }\end{array}$ \\
\hline
\end{tabular}

Tabel 5. Hasil Pengujian Alat Tahap Kedua

\begin{tabular}{|c|c|c|}
\hline No & Pengujian & Kemampuan \\
\hline 1 & RTC & $\begin{array}{l}\text { RTC (Real time Clock) mampu menhitung waktu atau menampilkan jam dan tanggal dengan } \\
\text { baik dan ketika alat di matikan } \pm 1 \text { jam setelah di hidupkan kembali RTC sudah dapat } \\
\text { menyimpan waktu dengan baik sesuai dengan waktu pada umumnya. }\end{array}$ \\
\hline 2 & Speaker & Speaker telah mampu untuk memberikan output seuara dengan baik. \\
\hline 3 & LCD $16 \times 2$ & $\begin{array}{l}\text { LCD (liquid Crystal Display)sudah dapat menampilkan text atau tulisanyang di tanamkan pada } \\
\text { Program mikrokontroller untuk ditampilkan pada LCD dan telah sesuai dengan program yang } \\
\text { telah di tanamkan pada mikrokontroller. }\end{array}$ \\
\hline 4 & $\begin{array}{l}\text { Aplikasi } \\
\text { Pada } \\
\text { Komputer }\end{array}$ & $\begin{array}{l}\text { Aplikasi interface pada komputer dengan visual basic } 6.0 \text {, setelah di racang desain aplikasi dan } \\
\text { di berikan listing program. Program jalan dengan baik tetapi masih ada sidikit kekurangan pada } \\
\text { tombol setbaca yang di fungsikan untuk memutar murottal melalui aplikasi pada komputer. }\end{array}$ \\
\hline 5 & $\begin{array}{l}\text { Rangkaian } \\
\text { Mikro } \\
\text { Kontroller }\end{array}$ & $\begin{array}{l}\text { Penanaman program pada mikrokontroller dapat beroprasi dengan baik akan dan mampu untuk } \\
\text { membaca SD Card akan tetapi format murottal yang dapat di putar hanya file yang berformat } \\
\text { *.wav dengan kapasitas frekuensi rendah dikarenakan setelah dilakukan berulangkali file } \\
\text { dengan format lain seperti MP3 dan WAV dengan kapasitas frekuensi tunggi rangkaian tidak } \\
\text { dapat membaca file yang ada pada SD Card. }\end{array}$ \\
\hline
\end{tabular}


Tabel 6. Hasil Pengujian Tahap Ketiga

\begin{tabular}{|c|c|c|c|c|c|}
\hline \multirow[b]{2}{*}{ No } & \multirow[b]{2}{*}{ Kemampuan } & \multicolumn{3}{|c|}{ Waktu } & \multirow[t]{2}{*}{ Ket } \\
\hline & & 10 menit & 20 menit & 30 menit & \\
\hline 1 & RTC & $\begin{array}{l}\text { RTC Mampu } \\
\text { membaca waktu } \\
\text { yang telah di } \\
\text { tetapkan untuk } \\
\text { memutar murrottal }\end{array}$ & $\begin{array}{l}\text { RTC Mampu } \\
\text { membaca waktu } \\
\text { yang telah di } \\
\text { tetapkan untuk } \\
\text { memutar murrottal }\end{array}$ & $\begin{array}{l}\text { RTC Mampu } \\
\text { membaca waktu } \\
\text { yang telah di } \\
\text { tetapkan untuk } \\
\text { memutar murrottal }\end{array}$ & $\begin{array}{l}\text { Dari hasil pengujian } \\
\text { RTC dapat bekerja } \\
\text { dengan baik }\end{array}$ \\
\hline 2 & $\begin{array}{l}\text { Rangkaian } \\
\text { mikrokontroller }\end{array}$ & $\begin{array}{l}\text { dapat menerima dan } \\
\text { membaca perintah } \\
\text { dari RTCdengan } \\
\text { waktu yang telah di } \\
\text { tetapkan }\end{array}$ & $\begin{array}{l}\text { dapat menerima dan } \\
\text { membaca perintah } \\
\text { dari RTCdengan } \\
\text { waktu yang telah di } \\
\text { tetapkan }\end{array}$ & $\begin{array}{l}\text { dapat menerima dan } \\
\text { membaca perintah } \\
\text { dari RTCdengan } \\
\text { waktu yang telah di } \\
\text { tetapkan }\end{array}$ & $\begin{array}{l}\text { Dari hasil pengujian } \\
\text { Rangkaian } \\
\text { microkontroller } \\
\text { dapat bekerja } \\
\text { dengan baik }\end{array}$ \\
\hline 3 & $\begin{array}{l}\text { Aplikasi pada } \\
\text { komputer }\end{array}$ & $\begin{array}{l}\text { Dapat terhubung dan } \\
\text { memberi perintah } \\
\text { pada rangkaian alat }\end{array}$ & $\begin{array}{l}\text { Dapat terhubung dan } \\
\text { memberi perintah } \\
\text { pada rangkaian alat }\end{array}$ & $\begin{array}{l}\text { Dapat terhubung dan } \\
\text { memberi perintah } \\
\text { pada rangkaian alat }\end{array}$ & $\begin{array}{l}\text { Dari hasil pengujian } \\
\text { Aplikasi dapat } \\
\text { bekerja dengan baik }\end{array}$ \\
\hline 4 & Speaker & $\begin{array}{l}\text { Dapat output } \\
\text { mengeluarkan suara } \\
\text { murottal dengan } \\
\text { suratyang telah } \\
\text { dipilih } \\
\end{array}$ & $\begin{array}{l}\text { Dapat mengeluarkan } \\
\text { output suara } \\
\text { murottal dengan } \\
\text { suratyang telah } \\
\text { dipilih }\end{array}$ & $\begin{array}{l}\text { Dapat mengeluarkan } \\
\text { output suara } \\
\text { murottal dengan } \\
\text { suratyang telah } \\
\text { dipilih } \\
\end{array}$ & $\begin{array}{l}\text { Dari hasil pengujian } \\
\text { speaker dapat } \\
\text { bekerja dengan baik }\end{array}$ \\
\hline 5 & LCD $16 \times 2$ & $\begin{array}{l}\text { Dapat menampilkan } \\
\text { output berupa } \\
\text { tulisan tanggal, } \\
\text { waktu dan surat } \\
\text { yang telah di pilih } \\
\text { untuk di putar }\end{array}$ & $\begin{array}{l}\text { Dapat menampilkan } \\
\text { output berupa } \\
\text { tulisan tanggal, } \\
\text { waktu dan surat } \\
\text { yang telah di pilih } \\
\text { untuk di putar }\end{array}$ & $\begin{array}{l}\text { Dapat menampilkan } \\
\text { output berupa } \\
\text { tulisan tanggal, } \\
\text { waktu dan surat } \\
\text { yang telah di pilih } \\
\text { untuk di putar }\end{array}$ & $\begin{array}{l}\text { Dari hasil pengujian } \\
\text { LCD dapat bekerja } \\
\text { dengan baik }\end{array}$ \\
\hline
\end{tabular}

\section{B) Saran}

Disarankan agar mengembangkan dari pada alat ini dengan melengkapi jadwal sholat pada rancangan secara digital dikarenakan pada penelitian kali ini belum dicantumkan jadwal sholat secara digital.

\section{DAFTAR PUSTAKA}

Bin Ladjamudin. Al-Bahra. 2005. Analisis dan Desain Sistem Informasi.Graha Ilmu. Jakarta.

Dian. Artanto. 2012.Interaksi Arduino dan labVIEW. Elex Media.Komputindo. Jakarta.

Indoware. Apa itu Arduino.www.indo-ware.com. Diakses pada 10 mei 2015

Jogiyanto. HM.2005.Analisis dan Desain Sistem Informasi. Andi.Yogyakarta.

Modul Arduino. 2015. Panduan Penggunaan Arduino dengan IDE Arduino. Elex Media. Jakarta.

Pranata Abdullah, 2012. Dasar-dasar Metodologi Penelitian.Elek Media Koputindo. Jakarta.

Susilo Deddy, 2010. Pengenalan Mekatronika Dasar. Yogyakarta. Graha Ilmu
Supriyanto. Aji. 2005. Pengantar Teknologi Informasi. Semarang. Salemba Infotek.

Widodo. Budiharto. 2005. Panduan Lengkap Belajar Mikrokontroler Perancangan Sistem dan Aplikasi Mikrokontroler. Jakarta. PT Elek Media Komputindo. 